\title{
VALUE CHAIN DAN POLA PENGEMBANGAN KELEMBAGAAN KOMODITI RUMPUT LAUT (Kappaphycus alvarezii) DI KABUPATEN PULAU MOROTAI
}

\section{Value Chain and Institutional Development Pattern of Seaweed Commodity (Kappaphycus alvarezii) In Morotai Island Regency}

\author{
*Admi Athirah, Ruzkiah Asaf dan Tarunamulia \\ Balai Riset Perikanan Budidaya Air Payau dan Penyuluhan Perikanan \\ Jalan Makmur Daeng Sitakka No. 129 Maros 90512, Sulawesi Selatan, Indonesia \\ Diterima tanggal: 14 Agustus 2019 Diterima setelah perbaikan: 22 Maret 2021 \\ Disetujui terbit: 25 Juni 2021
}

\begin{abstract}
ABSTRAK
Salah satu komoditi di Desa Kolorai Kabupaten Pulau Morotai adalah rumput laut (Kappaphycus alvarezii). Untuk menghadapi tantangan perdagangan saat ini, komoditi yang dapat bersaing adalah yang memiliki added value yang besar. Dalam perkembangannya, komoditi ini memiliki banyak kendala diantaranya dalam hal pemasaran, pengolahan hasil produksi, belum optimalnya kegiatan budi daya rumput laut, lemahnya sumber daya manusia dan kelembagaan serta harga rumput laut di pasaran yang kadang sangat murah. Penelitian dilakukan untuk mengetahui upaya pengembangan usaha budi daya rumput laut dengan analisis value chain dan pola pengembangan kelembagaan di daerah tersebut. Analisis deskriptif eksploratif dilakukan dengan gabungan pendekatan kualitatif dan kuantitatif. Pengumpulan data melalui proses pengamatan dan wawancara dengan para nelayan, pengumpul, pemerintah desa dan kabupaten yang menjadi sampel dalam penelitian. Metode analisis yang digunakan adalah SCAM (System Commodity Assessment Method). Hasil penelitian menunjukkan bahwa value chain rumput laut di Kabupaten Pulau Morotai terdiri dari beberapa tahapan yaitu pra produksi, produksi, distribusi, pengolahan dan konsumen, dengan nilai tambah pada setiap tahapan yang diperoleh. Karakteristik pada rantai nilai bersifat Rantai Produksi Tradisional. Pola rantai nilai dari produsen sampai ke konsumen terdiri atas: (1) produsen - pengumpul -Pedagang Ternate; (2) produsen - pengumpul - supplier - pedagang Ternate; dan (3) produsen - supplier - pedagang Ternate. Nilai tambah yang diberikan pada tingkat petani yaitu: pemanenan, penjemuran, pembersihan, pengemasan. Nilai tambah yang diberikan pada tingkat pengumpul, yaitu: transportasi, penjemuran, pembersihan, pengemasan ulang, penimbangan, serta penyimpanan. Hasil rantai nilai yang diperoleh terdapat kelemahan dan keterbatasan informasi teknologi pemasaran hasil produksi. Rekomendasi kebijakan untuk potensi komoditi ke depan adalah pendanaan modal, infrastruktur dan ketersediaan teknologi.
\end{abstract}

Kata Kunci: value chain; pengembangan kelembagaan; rumput laut; Desa Kolorai

\section{ABSTRACT}

Seaweed (Kappaphycus alvarezii) is one of the commodities in Kolorai Village, Morotai Island Regency. A competitive commodity with a high added value is necessary to face trade challenges. There are many problems in seaweed production in terms of marketing, product processing, non-optimal seaweed farming, poor institutional and human resources, and low proce of seaweed in the market. The study is attempted to develop seaweed farming with value chain analysis and institutional development patterns in the area. Exploratory descriptive analysis was conducted by combining qualitative and quantitative methods. Data were collected through a process of observation and interviews with fishers, collectors, village and district government as the samples of the study. The analytical method used is SCAM (System Commodity Assessment Method). The results showed that the value chain of seaweed in Morotai Island Regency consist of several stages, they are pre-production, production, distribution, processing and consumers, with added value obtained at each stage. Characteristics in the value chain are Traditional Production Chains. The value chain pattern from producers to consumers consists of: (1) producers - collectors - Ternate traders; (2) producers - collectors - suppliers - Ternate traders; and (3) producers - suppliers - traders of Ternate. The added values provided at the farmers are: harvesting, drying, cleaning, packaging. The added value provided at the collector level are: transportation, drying, 
cleaning, repackaging, weighing and storage. The results of the value chain reveal some weaknesses and limited information on marketing technology of the product. The study recommends some policies for future commodities, they are capital, infrastructure and technology.

Keywords: value chain; institutional development; seaweed; Kolorai village

\section{PENDAHULUAN}

Kabupaten Pulau Morotai telah ditetapkan sebagai kawasan minapolitan, sesuai dengan Keputusan Bupati Nomor 523.3/17/PM/2010, lokasi kawasan berada di Kecamatan Morotai Selatan, Kecamatan Morotai Selatan Barat sebagai kawasan inti (minapolis), serta Kecamatan Morotai Utara, Kecamatan Morotai Jaya, Kecamatan Morotai Timur sebagai kawasan penyangga (hinterland). Komoditas unggulan yang dikembangkan yaitu rumput laut dan kerapu. Kenaikan produksi rumput laut dan kerapu setiap tahun dari tahun 2011-2014 adalah 33,76\% dan 38,89\%, (PNPM Mandiri Pengolahan Hasil Perikanan Kementerian Kelautan dan Perikanan, 2014). Hal tersebut masih sangat rendah dibandingakan dengan potensi perikanan laut Morotai yang sangat tinggi dengan kondisi kualitas perairan yang tenang dan luasnya kawasan pesisir dan laut, yang memungkinkan untuk peningkatan pengembangan budi daya laut, terutama ikan kerapu, lobster, rumput laut dan mutiara.

Permasalahan atau isu strategis yang muncul dalam pengembangan komoditas unggulan di sektor perikanan adalah sarana dan prasarana kurang memadai, pelabuhan perikanan samudra belum termanfaatkan secara optimal, listrik untuk pabrikasi tidak memadai, kondisi jalan sampai di daerah sentra produksi tidak memadai serta bandar udara untuk ekspor langsung belum ada peningkatan pengetahuan dan keterampilan dari sini SDM masih diperlukan untuk pembudi dayaan dan pengolahan hasil perikanan (Kementerian PPN/Bappenas, 2014)

Adanya komoditas unggulan di suatu daerah usaha pengembangan secara optimal perlu diupayakan agar dapat memberikan keuntungan kepada nelayan, baik secara biofisik, sosial maupun ekonomi. Suatu komoditas layak dikembangkan jika komoditas tersebut diusahakan sesuai dengan zona agroekologinya, mampu memberi peluang berusaha, serta dapat dilakukan dan diterima masyarakat setempat sehingga berdampak pada penyerapan tenaga kerja dan secara ekonomi menguntungkan (Susanto \& Sirappa, 2007). Strategi pengembangan komoditas berkelanjutan dilakukan dengan mengembangkan suatu produksi sesuai dengan kebutuhan, menciptakan pola tanam yang merata sepanjang tahun, meningkatkan daya saing dan kemampuan Sumber Daya Manusia (SDM), menguatkan kelembagaan nelayan, permodalan, dan pemasaran, serta mengoptimalkan penggunaan lahan serta sarana dan prasarana (Taufik, 2012). Masyarakat (swasta) bersama pemerintah bekerjasama atau bermitra dalam posisi yang seimbang dan saling menghormati untuk menghasilkan sesuatu yang berguna bagi masing-masing pihak. Mekanisme kerjasama yang dijalankan oleh pemerintah dengan sektor swasta dengan cara berbagi sumber daya, pengetahuan, dan risiko dalam rangka peningkatan efisiensi produksi dan distribusi produk dan jasa hingga menghasilkan berbagai manfaat (Hartwich et al., 2007). Kemitraan membutuhkan komitmen dari seluruh pemangku kepentingan yang terlibat didalamnya. Ponnusamy (2013) menyatakan bahwa kerjasama kemitraan memerlukan landasan faktor kepercayaan, keterbukaan, dan kepatuhan pada kesepakatan (sesuai perjanjian). mekanisme kerja yang sesuai dan didukung oleh berbagai kebijakan dan instrumen yang tepat sangat diperlukan. Sebagaimana dilaporkan Calestous (2012), untuk menghadapi tantangan perdagangan bebas kedepannya, komoditi yang dapat bersaing adalah komoditi yang mempunyai added value yang besar, dan hal tersebut dibutuhkan dalam upaya pengembangan budi daya rumput laut, pola pengembangan kelembagaan partnership terhadap komoditi unggulan daerah.

Salah satu komoditi unggulan di desa Kolorai Kabupaten Pulau Morotai adalah rumput laut jenis Kappaphycus alvarezii, komoditi ini sangat penting untuk diperhatikan, karena rumput laut jenis ini telah lama menjadi mata pencaharian utama penduduk pesisir di Kabupaten Pulau Morotai. Komoditi ini mengalami perkembangan yang sangat pesat dalam added value, namun dalam pengembangan dan peningkatan produksi baik dalam bentuk basah dan olahannya masih sedikit diusahakan, permasalahan yang ditemukan dari segi sarana dan prasarana dan keterampilan pembudi daya dalam pengolahan produksi masih terlalu minim. Dari uraian tersebut maka tujuan dari penelitian 
yaitu untuk mengetahui upaya pengembangan usaha budi daya rumput laut dengan analisis value chain dan pola pengembangan kelembagaan di daerah tersebut. Value chain (rantai nilai) kegiatan mulai dari pasokan bahan baku (supply chain), proses produksi (production) dan pemasaran (marketing) serta bagaimana mengembangkan dan meningkatkan produksi dan olahannya melalui pola pengembangan kelembagaan kemitraannya.

\section{METODOLOGI}

\section{Lokasi dan Waktu Penelitian}

Penelitian ini dilaksanakan pada bulan Agustus 2016 di Desa Kolorai, Kecamatan Morotai Selatan, Kabupaten Pulau Morotai. Provinsi Maluku Utara. (Gambar 1. Peta Lokasi Penelitian). Lokasi penelitian merupakan daerah perairan yang sangat cocok untuk pengembangan budi daya Rumput laut, baik dengan menggunakan metode Patok dasar maupun Longline, komoditas ini sudah sejak lama dan sudah banyak yang melakukan usaha budi daya ini yaitu penduduk di pulau-pulau kecil di bagian Barat P. Morotai, seperti di P. Kolorai, P. Ngele-ngele dan P. Galo-galo.

\section{Jenis dan Metode Pengambilan Data}

Teknik pengambilan data dilakukan dengan mengambil data primer dan data sekunder. Data primer yang dibutuhkan berupa rantai nilai produksi dalam aktivitas utama dan pendukung, hal tersebut diperoleh dengan melakukan observasi ke lapangan dan wawancara langsung dengan sasaran para stakeholders yang meliputi tokoh masyarakat, pejabat pemerintah, kelompok dunia usaha dan industri, dan pembudi daya rumput laut. Jumlah responden pembudi daya rumput laut adalah sejumlah 20 orang dan dari stakeholders terkait sejumlah 6 orang. Teknik sampling digunakan yaitu dengan cara purposive sampling, sampel yang diteliti sebagai responden dengan pertimbangan bahwa responden yang dipilih merupakan responden yang berkompeten dan

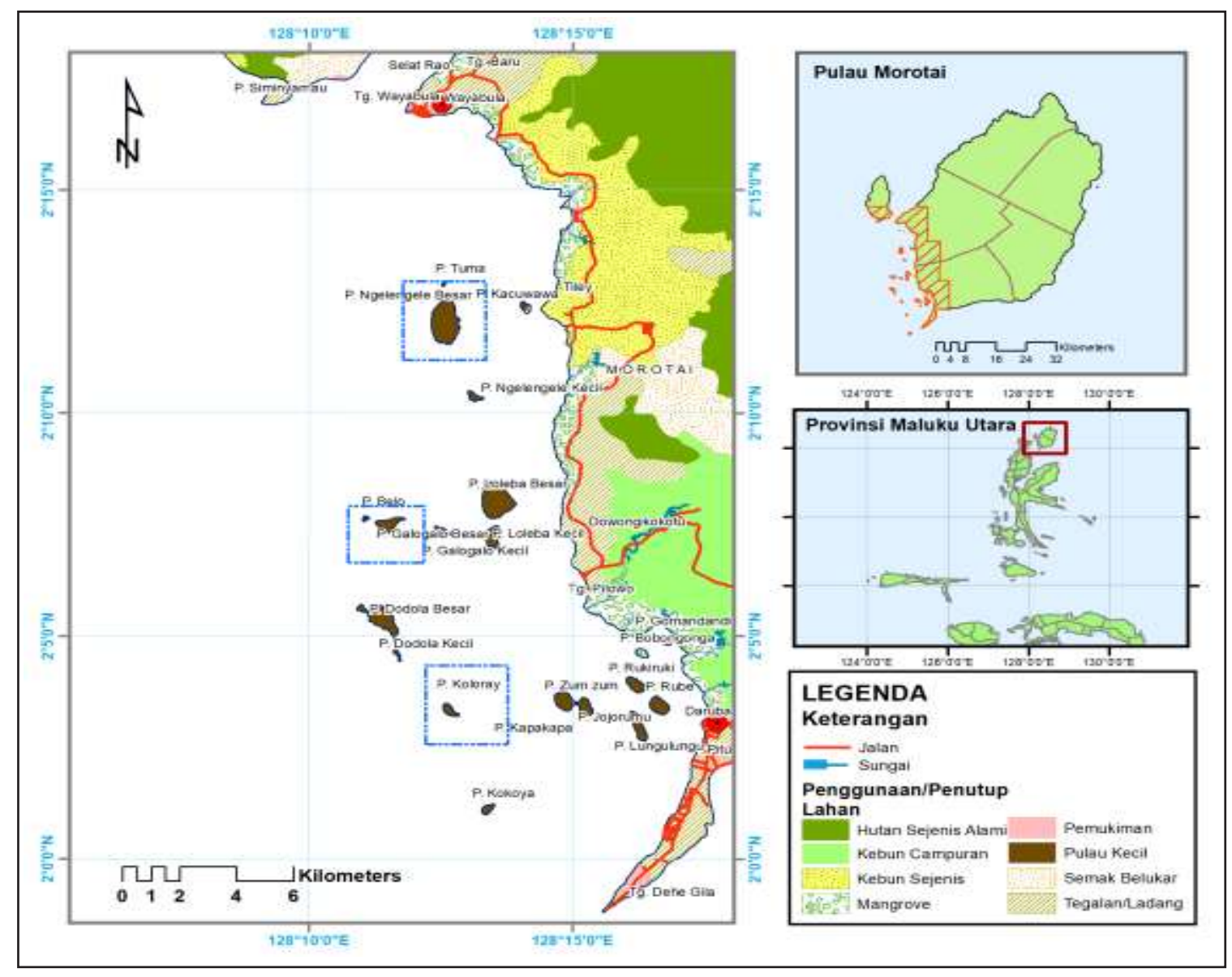

Gambar 1. Peta Lokasi Penelitian.

Picture 1. Location Map.

Sumber/ Source: Tarunamulia, Hasnawi, Taukhid \& Kamariah. (2020) 
memiliki pengalaman kerja minimal 1 (satu) tahun dalam rantai nilai. Data sekunder diperoleh dari berbagai instansi seperti Dinas Kelautan dan Perikanan, Badan Perencanaan Pembangunan Daerah, Badan Pusat Statistik Kabupaten Pulau Morotai, dan Instansi/lembaga/ badan terkait lainnya.

\section{Metode Analisis}

Metode penelitian dilakukan dengan SCAM (System Commodity Assessment Method), dilakukan dengan menggunakan alat survei berupa kuisioner yang disebarkan pada nelayan, pengumpul, pedagang besar, dan pengecer populasi yang diamati adalah nelayan, pengumpul, pedagang besar, dan pengecer yang terlibat dalam distribusi. Sistem penilaian komoditas berupaya mengidentifikasi kelemahan secara keseluruhan rantai nilai yang mengarah pada kerugian pangan (kerugian pascapanen) dan, pada saat yang sama, mengidentifikasi solusi dan untuk meningkatkan efisiensi.

SCAM menghasilkan informasi dasar dan pengetahuan yang diperlukan untuk memahami rantai nilai dan penting untuk perumusan kegiatan usaha yang berkualitas (La Gra, 2016). SCAM atau sistem penilaian komiditi adalah suatu metode penilaian sistem komoditi yang bertujuan untuk mengidentifikasi dan mendeskripsikan masalah serta mengidentifikasi dan memformulasikan pemecahan masalah yang tepat dari faktor-faktor dan cara-cara penanganan yang mempengaruhi mutu, kehilangan, kerusakan, kerugian secara ekonomi dalam rantai distribusi (Harsojuwono, 2008). Penerapan SCAM dan dengan diperkuatnya rantai distribusi maka akan diperoleh produk-produk berkualitas dan bermutu yang mampu bersaing di pasaran. Untuk menjaga mutu suatu komoditas maka diperlukan penanganan yang benar sehingga dihasilkan komoditi yang siap dipasarkan dengan mutu seperti keinginan konsumen. Metode SCAM diharapkan bisa mengevaluasi penanganan pascapanen dari petani ke konsumen. Dengan metode tersebut, penanganan pascapanen sejak awal sampai pemasarannya bisa dipantau. Selain hal tersebut dilakukan analisis dengan mengidentifikasi para pelaku yang terlibat dalam rantai nilai, identifikasi kelembagaan yang ada disepanjang rantai nilai dan analisis manfaat disetiap kegiatan. Identifikasi para pelaku yang terlibat sepanjang rantai nilai dilakukan melalui penelusuran dan keterkaitan. Selanjutnya memetakan hubungan antar aktor yang terlibat. Identifikasi kelembagaan atau aturan-aturan yang ada di sepanjang rantai nilai, hubungan antar aktor dan berupa hubungan principal agent yang terlibat di dalam rantai nilai.

\section{HASIL DAN PEMBAHASAN}

\section{Potensi Rumput Laut}

Potensi lahan yang tersedia untuk perikanan budi daya, mencapai 7134.30 ha, sementara lahan yang baru dimanfaatkan seluas 570.74 ha yang meliputi budi daya rumput laut seluas 389.84 ha, budi daya ikan kerapu seluas 34.32 ha, budi daya kerang mutiara seluas 4.21 ha dan budi daya sea ranching seluas 316.20 ha (Badan Pusat Statistik Kabupaten Pulau Morotai, 2016). Dari komoditas perikanan yang dibudi dayakan tersebut, komoditas yang menjadi unggulan di Kabupaten Pulau Morotai adalah Rumput laut, di mana produksi terbanyak dihasilkan oleh penduduk Pulau Galo-galo. Lokasi budi daya yang masih sangat luas di Morotai memungkinkan untuk pengembangan lebih lanjut. Akan tetapi, dalam 1-3 tahun ke depan, pengembangan budi daya belumlah menjadi prioritas utama, karena keterbatasan tenaga kerja yang berminat dalam kegiatan ini. Budi daya juga membutuhkan ketekunan dan keuletan tersendiri sehingga masyarakat perlu disiapkan sedini mungkin, karena terkait dengan budaya dan kebiasaan masyarakat Morotai. Akan tetapi, bila ada pasar yang menawarkan dengan harga yang bersaing dengan produk yang dihasilkan dari pekerjaan lain, maka akan dapat menjadi alternatif mata pencaharian bagi masyarakat Morotai.

Faktor oseanografi seperti fisiska, kimia, dan dinamika air laut sangat mempengaruhi pertumbuhan dan penyebaran rumput laut, serta jenis substratnya. Rumput laut banyak dijumpai pada daerah perairan yang dangkal (intertidal dan sublitorral) dengan kondisi perairan berpasir, sedikit lumpur, atau campuran keduanya.

Selama tahun 2010 sampai dengan tahun 2014, beberapa desa di kecamatan Morotai Selatan dan Morotai Barat terdapat kegiatan budi daya rumput laut, namun di tahun berikutnya nelayan tidak melakukan lagi kegiatan budi daya karena adanya masalah teknis budi daya yang belum sempurna, sulit mendapatkan bibit rumput laut yang sesuai dengan kondisi perairan, penyakit ice-ice dan harga komoditas yang anjlok dari 
$\mathrm{Rp} 12.000 / \mathrm{kg}$ ke Rp5.000/kg di tingkat nelayan, hal tersebut membuat kegiatan budi daya rumput laut tidak berlanjut lagi dan sangat disayangkan jika tidak ditindak lanjuti oleh pemerintah setempat.

\section{Daya Saing dan Globalisasi Pemasaran}

Daya saing suatu komoditas dapat diukur dengan menggunakan pendekatan keunggulan komparatif dan kompetitif. Pemahaman atas rantai nilai (value chain) menjadi salah satu aspek penting dimiliki semua pihak terutama petani rumput laut untuk menghadapi persoalan pasar. Analisis value-chain merupakan alat analisis stratejik yang digunakan untuk memahami secara lebih baik terhadap keunggulan kompetitif, untuk mengidentifikasi dimana value pelanggan dapat ditingkatkan atau penurunan biaya, dan untuk memahami secara lebih baik hubungan perusahaan dengan pemasok/supplier, pelanggan, dan perusahaan lain dalam industri (Porter, 1985). Value chain mengidentifikasikan dan menghubungkan berbagai aktivitas stratejik diperusahaan (Hansen \& Mowen, 2000). Rantai nilai mencakup seluruh kegiatan dan layanan untuk membawa suatu produk atau jasa dari tahap perencanaan hingga penjualan di pasar (Campbell, 2008), sistem dari langkah-langkah saling terkait penting untuk mengubah bahan mentah menjadi produk jadi untuk konsumen akhir, dimana setiap langkah tersebut menambah nilai produk (Otto, 2008)

Dari hasil analisis value chain dapat ditentukan suatu strategi dalam pengembangan usaha suatu komoditas yang menjadi unggulan di daerah tersebut, dengan tujuan dapat meningkatan pendapatan suatu daerah. Dengan adanya daya saing dan globalisasi pemasaran dapat menjadi dasar dalam pengembangan usaha. Hukum keunggulan komparatif ini menyatakan bahwa sekalipun suatu negara tidak memliki keunggulan absolut dan memproduksi dua jenis komoditas jika dibandingkan negara lain, namun perdagangan yang saling menguntungkan masih bisa berlangsung, selama rasio harga antar negara masih berbeda jika dibandingkan tidak ada perdagangan (Lindert \& Kindleberger, 1993).

Hasil pengumpulan data dan wawancara terhadap beberapa responden terkait dengan pengembangan usaha budi daya di Kabupaten Morotai, maka dilakukan analisis alur proses (saluran pemasaran) untuk membahas lebih lanjut keterkaitan antara sub proses yang berpengaruh terhadap pengembangan budi daya rumput laut di Kabupaten Pulau Morotai tersaji pada Gambar 2.

\section{Aliran produk}

Aliran produk merupakan aliran barang dari hulu (upstream) ke hilir (downstream) pada Gambar 2. Dari hasil analisis dan wawancara pada beberapa responden nelayan atau pembudi daya, menjual hasil budi daya mereka kepada pengumpul di daerah mereka masing-masing, hal tersebut mereka lakukan mengingat jarak mereka yang cukup jauh dari pusat perdagangan di Kabupaten Morotai atau daerah tempat penjualan hasil produk perikanan mereka, sepanjang tahap pertama proses aliran produk, produk yang dihasilkan masih berupa bahan mentah yang belum banyak mengalami pengolahan dengan sentuhan teknologi. Produk yang dihasilkan pasca panen masih berupa bahan yang dikeringkan untuk rumput laut, sedangkan hasil perikanan lainnya harus segera dipasarkan sebelum terjadi pembusukan pada hasil budi daya atau hasil tangkapan ikan. Kenyataan ini disebabkan ketiadaan teknologi pengolahan dan adanya pola hubungan dan pembiayaan yang mempengaruhi kekuatan tawar menawar antara para pelaku dengan pemodal pasca panen. Para pemodal memiliki kekuatan untuk menekan para pelaku untuk secepatnya mengembalikan modal

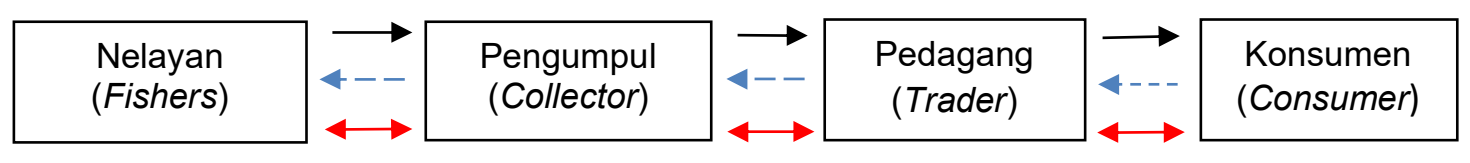

Keterangan/ Remarks:

Aliran Produk (Product Flow)

Aliran Informasi (Information Flow) : $\longrightarrow$

Aliran Keuangan (Financial Flow) :

\section{Gambar 2. Bagan Alur Proses Pemasaran Rumput Laut di Kab. Pulau Morotai. Picture 2. Flow Chart of Seaweed Marketing Process in Morotai Island.}


pinjaman yang telah mereka peroleh dan untuk menghindari beban bunga tambahan yang dapat dikenakan, dipihak lain para pelaku dibebani tanggungjawab untuk memenuhi kebutuhan keluarga.

\section{Aliran Informasi}

Aliran informasi merupakan aliran yang terjadi baik dari hulu ke hilir maupun sebaliknya dari hilir ke hulu. Informasi yang mengalir berkaitan dengan kondisi hasil produk budi daya, jumlah permintaan, harga, informasi terkait kualitas hasil produksi. Aliran informasi yang ada mengalir secara vertikal maupun secara horizontal. Aliran mengalir secara vertikal artinya terdapat koordinasi pada mata rantai yang berbeda yaitu antara pembudi daya, pedagang, pengusaha, pedagang pengecer dan konsumen. Sedangkan aliran secara horizontal artinya terdapat koordinasi pada sesama anggota mata rantai. Contoh adanya koordinasi secara horizontal yaitu adanya koordinasi antar pedagang hasil budi daya terkait dengan ketersediaan hasil produk budi daya yang ada di tingkat pembudi daya. dan adanya koordinasi antar sesama pengusaha hasil produk budi daya terkait jumlah hasil budi daya yang dimiliki menjadi bentuk adanya koordinasi secara horizontal.

\section{Aliran Keuangan}

Aliran keuangan merupakan perpindahan uang yang mengalir dari hilir ke hulu. Aliran keuangan mengalir dari konsumen hingga ke pembudi daya atau nelayan, pola aliran dalam rantai menunjukkan bahwa keuangan mengalir dari pedagang kepada pembudi daya. Sistem pembayaran dilakukan secara tunai dan akan terjadi transaksi apabila ada kesepakatan dan kesesuaian produk dengan harga yang ditawarkan oleh pembudi daya. Pedagang secara langsung akan membeli hasil produk budi daya di tempat pembudi daya yang ingin menjual kemudian melakukan transaksi tersebut.

Ketiga aliran tersebut mengalir pada mata rantai seperti pembudi daya/nelayan, pedagang pengecer, pengusaha, pedagang dan konsumen. Upaya untuk mengoptimalkan ketiga aliran yang ada pada rantai pasokan hasil kegiatan budi daya dapat dilakukan dengan pendekatan sistem dengan melibatkan beberapa pihak, seperti pembudi daya, pedagang pengecer, pengusaha, pedagang, konsumen dan pihak pemerintah sebagai penentu kebijakan. Persediaan produk hasil kegiatan budi daya di Kabupaten Pulau Morotai dinilai masih sangat kurang karena para nelayan atau pembudi daya hanya bergantung dengan modal yang diberikan kepada masing-masing kelompok pembudi daya dan adanya kendala dalam melakukan budi daya yaitu kondisi kualitas air budi daya dan adanya penyakit yang ditemukan dalam melakukan kegiatan budi daya yang berpengaruh terhadap hasil produksi budi daya. Pihak yang berperan dalam pasokan hasil produk kegiatan budi daya adalah nelayan atau pembudi daya karena apabila mereka tidak melakukan budi daya secara optimal maka ketersediaan hasil budi daya tidak akan terpenuhi sampai ketingkat konsumen, untuk pemenuhan tersebut kerjasama pemerintah dalam hal ini sangat dibutuhkan dalam hal kebijakan dan ketersediaan teknologi dan modal dalam melakukan usaha budi daya.

Value chain rumput laut di Kabupaten Pulau Morotai dilihat dari beberapa tahap yaitu pra produksi, produksi, distribusi, pengolahan dan konsumen akhir. Pada tahap pra produksi, dibutuhkan penyediaan alat budi daya, dan penyediaan bibit untuk membantu produksi rumput laut. Benih rumput laut diperoleh dari Manado setelah itu pembudi daya mengusahakan sendiri atau memperoleh dari pembudi daya lain dalam desa yang sama. Metode budi daya yang dilakukan nelayan pada kegiatan rumput laut adalah metode tali ris atau long line dengan jumlah bentangan yang dimiliki rata-rata 88 dan panjang tali ris rata-rata $15 \mathrm{~m}$. Dari hasil anlisis diperoleh penggunaan bibit oleh pembudi daya minimal 4 $\mathrm{kg}$ per tali ris, yang menunjukkan bahwa untuk satu bentangan tali risi dengan panjang $10 \mathrm{~m}$ dibutuhkan 100gram bibit per rumpun. Untuk tali ris yang panjangnya $15 \mathrm{~m}$ bibit yang di gunakan 150 gram per rumpun. Arah tali ris terhadap garis pantai adalah tegak lurus. Bahan untuk pelampung pembudi daya menggunakan botol palstik. Untuk satu musim tanam petani nelayan membutuhkan biaya sebesar Rp4.606.667,-. Lama pemeliharaan rumput laut yang dilakukan responden untuk dikeringkan rata-rata 52 hari, dan untuk bibit lama pemeliharannya rata-rata 38 hari. Lamapengeringan rumput laut rata-rata 4 hari dengan produksi rata-rata satu bentangan tali lis adalah $38,18 \mathrm{~kg}$. Hasil rumput laut tersebut kemudian didistribusikan ke penampung kemudian ke pedagang pengumpul melalui perantaraan pengumpul lokal. Terlihat dari jalur tersebut belum adanya upaya pemasaran lokal dalam bentuk produk olahan rumput laut. Penjualan lokal terbatas dalam bentuk rumput laut basah sebagai bibit ke petani lainnya dan berupa 
rumput laut kering.

Pada masing-masing tahapan rantai nilai (value chain) tersebut terdiri dari beberapa pelaku utama yang masing-masing memiliki fungsi dan tujuan yang sama yaitu memperoleh keuntungan.

Tahap pembibitan adalah berupa bibit yang siap tanam sedangkan nilai yang didapatkan dari penjual alat budi daya adalah penyediaan alat tersebut. Permasalahan yang ditemukan pada pra produksi baik pembibitan maupun penjualan peralatan budi daya adalah input produksi, yang masih didapatkan dari luar.

Tahap produksi, dimana yang terlibat adalah pembudi daya, pengikat tali ris dan pengikat bibit. Pembudi daya ini berfungsi untuk menanam dan memanen rumput laut, sedangkan untuk pengikat tali ris untuk meyiapkan tali sebagai alat tempat budi daya rumput laut, pengikat bibit berfungsi untuk mengikat bibit rumput laut. Ketiga pelaku utama bertujuan untuk mendapatkan keuntungan bagi pembudi daya, sedangkan dua pelaku lainnya bertujuan untuk mendapatkan upah, namun hanya beberapa nelayan yang menggunakan tenaga orang lain dalam melakukan usahanya, sebagaian lain dikerjakan sendiri bersama anggota keluarganya. Nilai yang diperoleh dari pembudi daya adalah pembesaran dan pengeringan rumput laut, sedangkan untuk pengikat tali ris dan bibit masing-masing memiliki nilai yaitu sarana produksi yang siap pakai dan rumput laut yang siap tanam. Masalah yang ditemukan pada tahapan produksi adalah pada saat kondisi salinitas tinggi, benih dipakai berkali-kali selama setahun, dan kurangnya informasi pasar.

Tahap distribusi melewati proses memindahkan rumput laut dari petani produsen ke tingkat yang lebih tinggi. Pada proses ini melewati beberapa pelaku seperti pengumpul kecil, biasanya pada prakteknya disebut tengkulak, pengumpul besar, pedagang besar, dan ekportir. Masingmasing pelaku utama ini memiliki fungsi yaitu: pengumpul kecil berfungsi menampung rumput laut dari pembudi daya dan menyalurkannya ke pengumpul besar, pengumpul besar berfungsi menampung rumput laut dari pengumpul kecil serta pembudi daya dan menyalurkan ke pedagang besar, pabrik dan eksportir, mereka memiliki fungsi yang sama sebagai pengumpul bahan baku rumput laut dari pengumpul untuk diekspor dalam bentuk kering. Semua pelaku utama (pengumpul kecil, pengumpul besar dan penampung) memiliki tujuan yang sama yaitu mendapatkan keuntungan, Nilai yang diperoleh pada tahapan distribusi ini adalah menyalurkan (distribusi) rumput laut, melakukan proses packaging yang selanjutnya dipasarkan. Permasalahan yang ada pada pelaku utama ini adalah ketidaktahuan mereka tentang harga di pasar eksportir.

Tahap pengolahan terdiri dari industri besar dan pengolahan tingkat rumah tangga. Kegiatan pemasaran rumput laut dilanjutkan oleh perusahaan besar baik dengan memasarkan ke luar negeri dalam bentuk rumput laut kering maupun dalam bentuk hasil olahan berupa ATC/chip dan SRC ke negara tujuan seperti China, Jepang dan Eropa. Kedua pelaku utama ini memiliki tujuan yang sama yaitu mendapatkan keuntungan, dan memberdayakan masyarakat di sekitarnya pada pengolahan tingkat rumah tangga. Komoditas rumput laut yang ada di Kabupaten Pulau Morotai ini memiliki banyak permasalahan yang ditemukan di setiap pelaku utama. Masalah yang ditemukan pada pembudi daya diantaranya adalah teknologi, akses terhadap pasar, input produksi dan jasa, lemahnya posisi tawar, kompetisi dengan pembudi daya besar (pengusaha) dan kurangnya informasi pasar. Pada tingkat pengumpul kecil adanya keterkaitan antara pembudi daya dengan pengumpul. Pada tingkat pengumpul besar masalah yang dihadapi adalah harga pada eksportir, yang menyulitkan pengumpul besar dalam menentukan harga pada tingkat pengumpul kecil dan pembudi daya.

Pada tingkat pengolahan, adanya persaingan tingkat domestik yang belum memiliki akses pasar, serta market share relatif kecil dan pada pasar internasional adanya persaingan dengan negara lain, dari sisi non tarif barier yaitu dari sisi kualitas rumput laut yang sesuai dengan standar internasional. Pada tahap pengekspor masalahnya adalah dalam hal logistik dan SCM (Supply Chain Management) yang berkaitan dengan efektivitas dan efisiensi produk olahan rumput laut.

Tahap terakhir yaitu permasalahan pada tingkat konsumen sebagai pengguna akhir produk olahan rumput laut laut yaitu keamanan hasil produk rumput laut, harga dan konsistensi keberlanjutan.

\section{Produksi dan Pendapatan}

Hasil akhir yang diharapkan bagi pembudi daya dari usahanya adalah produksi. Produksi dan pendapatan responden dapat dilihat pada Tabel 1. 
Tabel 1. Analisis Finansial Usaha Budi Daya Rumput Laut Permusim Tanam, di Desa Kolorai, Kecamatan Morotai Selatan, 2016.

Table 1. Financial Analysis of Seaweed Farming Crops Per Season, In The Village of Kolorai, Sub Regency of South Morotai, 2016.

\begin{tabular}{|c|c|c|}
\hline No & Uraian/Description & $\begin{array}{l}\text { Jumlah/Amount } \\
\text { (Rp/ldr) }\end{array}$ \\
\hline 1 & $\begin{array}{l}\text { Penerimaan//ncome: Produksi }(85 \times 38,18 \mathrm{~kg} / \text { tali ris }) \times \mathrm{Rp} 5000 / \\
\text { Production }(85 \times 38,18 \mathrm{~kg} / \text { /ris rope })\end{array}$ & $16,226,500$ \\
\hline 2 & $\operatorname{PPh}(15 \%) / \operatorname{Tax}(15 \%)$ & $2,433,975$ \\
\hline 3 & Penerimaan setelah PPh (1-2)/After tax acceptance (1-2) & $13,792,525$ \\
\hline 4 & Biaya variabel/Variable vost & $3,270,000$ \\
\hline 5 & Biaya tetap/Fix cost & $1,338,667$ \\
\hline 6 & Total biaya (biaya variabel + biaya tetap)/Total cost (variable cost + fix cost) & $4,608,667$ \\
\hline 7 & Keuntungan (3-4)/Profit (3-4) & $9,183,858$ \\
\hline 8 & $\mathrm{R} / \mathrm{C}$ ratio $(1: 4) / R / C$ ratio $(1: 4)$ & 3.52 \\
\hline 9 & Pay back periode $=\frac{\text { Total Investasi/Cost Investmen }}{\text { Keuntungan/Profit }}$ & 1.16 \\
\hline
\end{tabular}

Penerimaan yang diperoleh lebih kecil dibanding penerimaan tahun pertama pada kegiatan rumput laut. Hal ini disebabkan karena selainharga jual yang rendah juga karena serangan hama dan penyakit ice- ice. Namun demikian pendapatan yang diperoleh responden masih menguntungkan. Hasil perhitungan R/C ratio menunjukan $>1$ yaitu 3,52 artinya setiap korbanan Rp1,- akan menghasilkan penerimaan sebesar 3,52 dengan pay back period juga cepat yaitu 1,16 bulan sehingga pengembalian investasi awal tidak memerlukan waktu lama. Dari hasil analisis tersebut dapat diketahui bahwa kegiatan budi daya rumput laut berpotensi untuk dijadikan sebagai kegiatan yang bermanfaat untuk nelayan di Desa Kolorai Kabupaten Pulau Morotai.

\section{Struktur rantai nilai dan Pola Pengembangan Kelembagaan}

Kegiatan yang dibutuhkan dalam produk melalui fase yang berbeda dari produksi yang melibatkan gabungan transformasi fisik dan adanya masukan dari berbagai layanan produser, pengiriman ke konsumen akhir, dan pembuangan akhir setelah digunakan adalah merupakan gambaran dari rantai nilai (Kaplinsky, 2000). Dalam konteks manajemen rantai nilai, nilai biasanya didefinisikan dalam persepsi pelanggan (downstream perusahaan berikutnya) atau konsumen (pembeli akhir dari barang jadi). Dalam defenisi nilai ada tiga hal yang berjalan yaitu: (1) Nilai pelanggan terkait dengan penggunaan produk atau layanan; (2) Nilai yang dirasakan oleh pelanggan, tidak ditentukan oleh penjual, dan (3) Nilai pelanggan biasanya melibatkan trade-off antara apa yang pelanggan inginkan dan apa yang harus diberikan dalam rangka untuk memperoleh dan menggunakan produk atau jasa. Berikut ini gambaran umum aktivitas utama produksi rumput laut di Kabupaten Pulau Morotai dalam bentuk Value chain.

Struktur manajemen dalam rantai nilai menjelaskan tentang aspek-aspek tindakan pada setiap tingkatan manajemen dalam anggota rantai. Manajemen yang diterapkan pada tingkat Nelayan, Pedagang Pengumpul Kabupaten Pulau Morotai dan Ternate masih bersifat sederhana. Pemilik langsung menjalankan seluruh proses bisnis pada rantai nilai. Pekerja yang digunakan masih bersifat buruh per unit kegiatan, dengan upah harian. Pada tingkat pemasok, struktur manajemen sudah lebih kompleks. Pemilik tidak terlibat langsung dalam proses pengolahan rumput laut. Pengolahan dilakukan oleh pekerja, yang digaji bulanan.

Hubungan kemitraan Pemilihan kemitraan pada rantai nilai bertujuan untuk menjamin terciptanya jalinan kerjasama yang saling menguntungkan. Intensitas kolaborasi pada kemitraan secara umum terbagi atas empat tingkatan, yakni Transactional Collaboration, Cooperative Collaboration, Coordinated Collaboration, dan Synchronized Collaboration (Gibson, Dunn \& Loveras, 2008). Tingkatan 


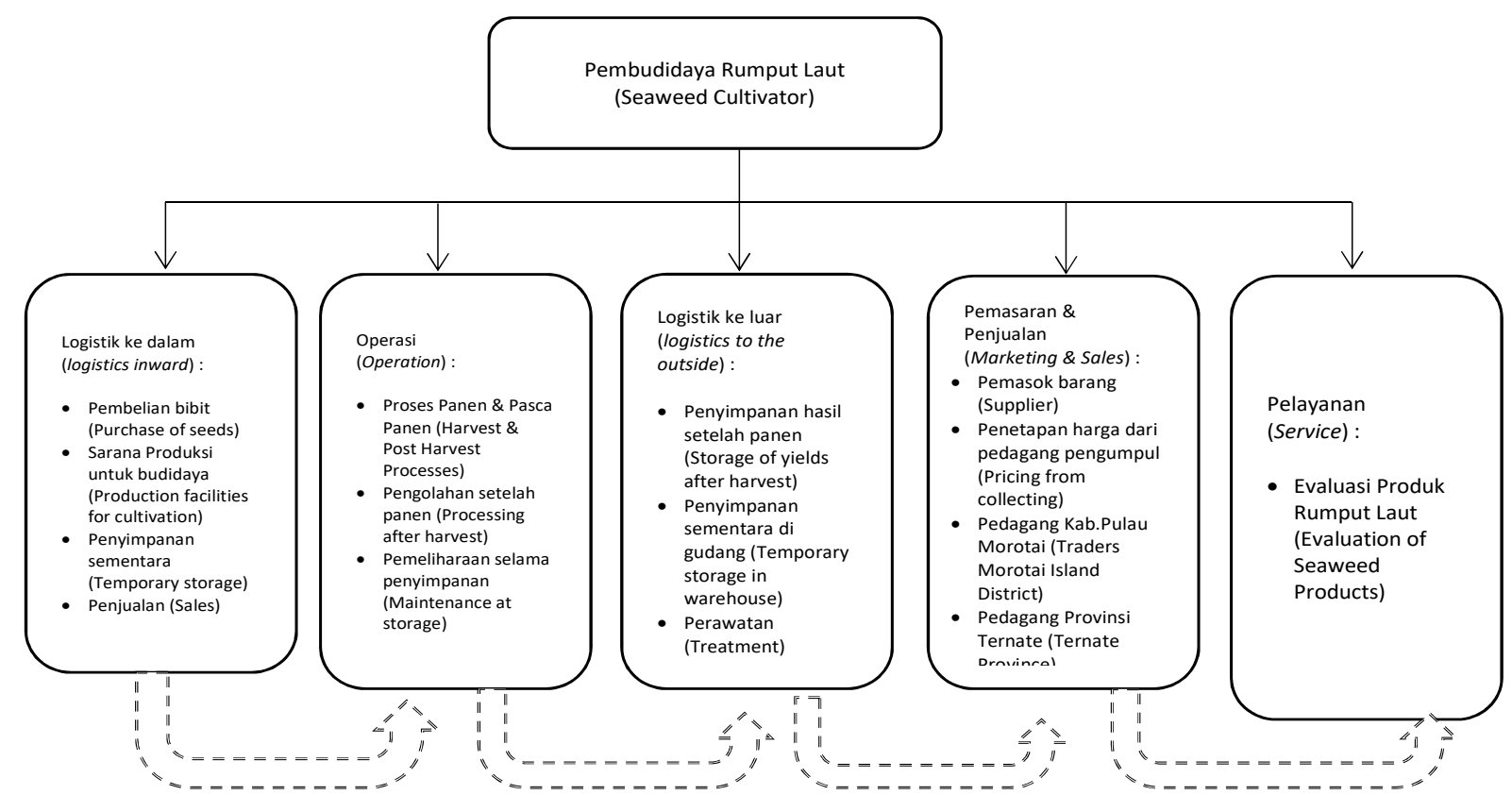

Gambar 3. Value Chain Rumput Laut di Kabupaten Pulau Morotai.

Figure 3. Seaweed Value Chain in Morotai Island District.

Transactional Collaboration yang terjadi di desa Kolorai dimana yang terjadi hanya hubungan transaksional adalah adanya kolaborasi yang terjadi dalam rantai nilai. Berikut tingkatan kolaborasi di Kabupaten Pulau Morotai:

Dalam prakteknya, pabrik sudah memberikan informasi terutama mengenai spesifikasi produk yang dibutuhkan oleh konsumen, baik itu dalam segi kemasan hingga ukuran yang digemari. Sistem transaksi dari Nelayan, pedagang perantara, pedagang pasar Kabupaten Pulau Morotai, pedagang pasar Ternate, menggunakan sistem pembayaran langsung. Sistim transaksi dari pemasok ke toko menggunakan sistem kontrak, dengan pembayaran secara periodik. Harga disepakati per periode pemesanan. Hasil identifikasi kelembagaan yang dibutuhkan di daerah tersebut adalah Kelembagan koperasi, dalam hal penyediaan modal, kelembagaan yang berkaitan dengan penyedia informasi berupa harga jual rumput laut, penanganan hama dan penyakit, serta pembibitan dan kelembagaan penyedia input (bibit, jangkar, bambu, perahu/sampan, tali, pelampung, alat pengering, dan sarana penyimpanan).

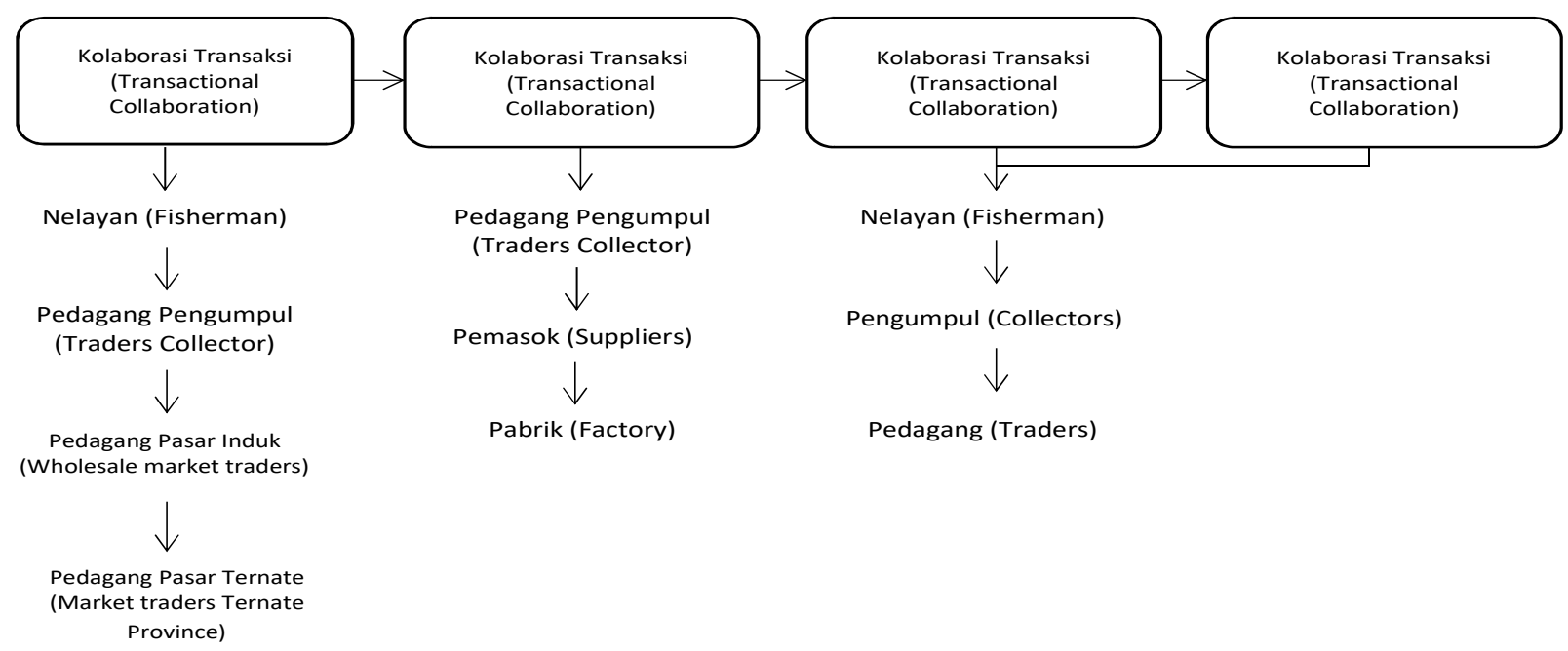

Gambar 4. Tingkatan Kolaborasi Rantai Nilai Rumput Laut di Kabupaten Pulau Morotai. Figure 4. Collaboration Level of Seaweed Value Chain in Morotai Island Regency. 
Dalam konteks kelembagaan kemitraan suatu usaha, kebijakan pemerintah memberi supporting ataupun guidance agar suatu program/kegiatan dapat berjalan seperti yang ditargetkan. Namun dalam tataran implementasi, seringkali terjadi misleading karena tidak adanya kepastian hukum yang tegas atau tidak sinkronnya sebuah produk kebijakan dengan kondisi riil di masyarakat. Implikasinya adalah kebijakan tersebut menjadi kurang efektif. Beberapa hal pokok yang perlu mendapatkan perhatian dalam kelembagaan kemitraan suatu usaha antara lain: (1) Pentingnya manajemen yang bersifat transparan, terutama menyangkut harga dan pembagian keuntungan; (2) Adanya komitmen yang tinggi antara pihak yang bermitra, sehingga terbangun saling percaya-mempercayai; (3) Penyediaan instalasi penanganan pasca panen dan pemasaran hasil yang memadai; (4) Adanya pendampingan dan pembinaan oleh tenaga ahli di bidang komoditas yang dikembangkan; serta (5) Konsolidasi kelembagaan kelompok nelayan, sehingga terbangun kelembagaan kelompok yang handal.

Aliran informasi merupakan faktor yang penting dalam rantai nilai. Berbagi informasi adalah suatu yang fundamental diperlukan dasar untuk mengintegrasikan anggota kolaborasi yang berbeda, meskipun kadangkadang dianggap sebagai berbagi risiko. Selain intermediasi, ini dapat menyebabkan asimetri informasi menghambat kejelasan informasi dan menambahkan nilai untuk pertukaran (Gibson et al., 2008). Aliran informasi antara pelaku harus dikelola dengan baik secara bersama untuk menghindari asymetric information yang akan menghambat efektifitas serta berpotensi menimbulkan kecurangan dalam suatu kemitraan. Informasi mengenai harga, mutu produk yang diinginkan, kuantitas produk yang diperlukan pasar, teknologi, serta isu-isu terbaru yang beredar di pasar, mutlak diperlukan oleh masing-masing anggota rantai. Pada kenyataannya, informasi sangat susah diperoleh, khususnya mengenai harga produk. Harga berubah setiap hari, dan masing-masing rantai harus mengakses harga secara harian. Nelayan biasanya mendapatkan informasi tentang harga dari pasar Kabupaten Pulau Morotai, sedangkan pedagang pasar Kabupaten Pulau Morotai mendapatkan informasi dari Pedagang perantara dan pemasok. Dalam hal penentuan harga, tidak ada kejujuran tentang, siapa yang menentukan harga.
Orientasi anggota rantai dapat diukur dengan menggunakan kinerja terkait delapan kriteria evaluasi, yaitu: keseimbangan antara harga dan nilai, transfer informasi, orientasi waktu, sifat alami hubungan, interaksi dalam rantai nilai, ketergantungan dalam rantai, kekuatan dalam rantai, serta orientasi dari anggota rantai. Kedelapan kriteria tersebut memungkinkan untuk memetakan berbagai karakteristik orientasi rantai produk segar, aktivitas, dan perilaku anggota rantai, dari penambahan nilai yang rendah, sedang, hingga berorientasi penuh pada nilai (Collins, 2009). Berdasarkan karakteristik aktivitas rantai nilai Collins, rantai produksi di Desa Kolorai Kabupaten Pulau Morotai bersifat Rantai Produksi Tradisional dimana keseimbangan antara harga dan nilai, mengutamakan harga dan dalam hal transfer informasi tidak terdapat pembagian informasi secara signifikan, waktu yang digunakan jangka pendek dan berdasarkan transaksi per transaksi, interaksi antara rantai nilai bersifat transaksi, ketergantungannya bersifat mandiri, kekuatannya individual dan memaksimalkan diri sendiri. Karakteristik pada rantai nilai: (1) produsen - pengumpul - pedagang; (2) produsen - pengumpul - supplier - pedagang; dan (3) produsen - supplier - pedagang.

\section{KESIMPULAN DAN REKOMENDASI KEBIJAKAN}

\section{Kesimpulan}

Rantai nilai rumput laut di Kabuten Pulau Morotai dariawal yaitu berdasarkan logistik ke dalam, tahap operasi, logistik ke luar, proses pemasaran dan penjualan, dan kemudian tahap pelayanan. Dari beberapa tahapan tersebut, masingmasing memiliki fungsi dan nilai tambah, serta permasalahan. Rantai nilai komiditi rumput laut (Kappaphycus alvarezii) di Desa Kolorai Kabupaten Pulau Morotai bersifat Rantai Produksi Tradisional. Pola rantai nilai dari produsen sampai ke konsumen terdiri atas: (1) produsen - pengumpul - pedagang Ternate ; (2) produsen - pengumpul - supplier - pedagang Ternate; dan (3) produsen - supplier - pedagang Ternate. Nilai tambah yang diberikan pada petani yaitu: pemanenan, penjemuran, pembersihan, pengemasan. Nilai tambah yang diberikan pada tingkat pengumpul, yaitu: tranportasi, penjemuran, pembersihan, pengemasan ulang, penimbangan, serta penyimpanan.

Potensi komoditi rumput laut dapat menjadi produk unggulan yang dapat bersaing 
di pasar domestik maupun internasional, dengan melakukan pengembangan dan peningkatan produksi, serta olahannya melalui pola pengembangan kelembagaan kemitraan. Kelembagaan yang penting dalam pengembangan usaha budi daya rumput laut tersebut adalah Kelembagan koperasi, dalam hal penyediaan modal, kelembagaan yang berkaitan dengan penyedia informasi berupa harga jual rumput laut, penanganan hama dan penyakit, serta pembibitan dan kelembagaan penyedia input (bibit, jangkar, bambu, perahu/sampan, tali, pelampung, alat pengering, dan sarana penyimpanan). Pentingnya dukungan kebijakan pemerintah dalam hal memberi supporting atau quidance agar suatu kegiatan usaha dapat berjalan sesuai target yang diinginkan

\section{Rekomendasi Kebijakan}

Perlunya pembinaan kapasitas nelayan rumput laut dalam hal pemasaran rumput laut, terutama bagi yang tidak terikat dengan modal pihak lain dengan fokus kegiatan diarahkan pada peningkatan kualitas dan perubahan pola pikir, selain itu pembudi daya penting untuk diperkenalkan teknologi pasca panen yang lebih baik sehingga produk yang dihasilkan sesuai dengan permintaan di tingkat eksportir/pasar internasional.

Perlunya pengembangan dalam hal pembibitan yang dilakukan secara individu maupun kelompok sebagai alternatif menjamin ketersediaan bibit secara berkesinambungan, hal tersebut sangat membantu pembudi daya karena dapat memberi nilai tambah yang lebih besar guna menambah total pendapatannya.

Pengembangan kelembagaan sangat penting untuk menjamin keberlanjutan usaha rumput laut, karena dengan adanya kelembagaan segala permasalahan yang ditemukan dapat diatasi, dengan memperhatikan beberapa hal pokok yaitu manajemen yang bersifat transparan, komitmen yang tinggi antara pihak yang bermitra, penyediaan instalasi, perlunya pendampingan dengan yang ahli dibidangnya dan konsolidasi antar kelompok nelayan.

\section{UCAPAN TERIMAKASIH}

Penelitian ini dibiayai oleh Anggaran Pendapatan dan Belanja Negara (APBN) Pusat Riset Perikanan Budi daya dan kepada seluruh peneliti maupun teknisi yang terlibat dalam pengumpulan data, bantuan teknis hingga selesainya seluruh rangkaian penelitian ini.

\section{PERNYATAAN KONTRIBUSI PENULIS}

Dengan ini kami menyatakan bahwakontribusi masing-masing penulis terhadap pembuatan karya tulis adalah: Admi Athirah sebagai kontributor utama, Ruzkiah Asaf dan Tarunamulia sebagai kontributor anggota.

\section{DAFTAR PUSTAKA}

Badan Pusat Statistik Kabupaten Pulau Morotai. (2016). Pulau Morotai Dalam Angka. Retrieved from http://Pulau Morotaikab.go.id.

Calestous, J. (2012). Preface: Building trust in agricultural biotechnology partnerships. Agriculture \& Food Security 1 (Supp/ 1):/1. Retrieved from http:// www.agriculture and food security.com/content/1/ S1/I1. doi: 10.1186/2048-7010-1-S1-I1

Campbell, R. (2008). Kerangka Kerja Rantai Nilai: Analisis sektor industri terkait dengan komponen struktural dan dinamis dari rantai tersebut adalah alat penting guna meningkatkan daya saing. competitiveness at the FRONTIER tema Rantai Nilai, Juli 2008. Retrieved from https://pdf.usaid. gov/pdf_docs/Pnads405.pdf.

Collins, R. (2009). Value Chain Management and Postharvest Handling: Partners in Competitiveness. Postharvest Handling: A System Approach. Edited by Wojciech J. Florkowski, Robert L. Shewfelt, Bernhard Brueckner, and Stanley E. Prussia. San Diego, CA, USA: Academic Press. 107-128. doi: 10.1016/B978-0-12-374112-7.00006-8

Gibson, P., Dunn, L., \& L. Loveras. (2008). Strategic Implications for Firms Competing in the Supply of Highly Perishable Goods - A Case Study in Cut Flowers. University of Wollongong, Wollongong, NSW 2522 Australia.

Hansen \& Mowen (2000). Management Biaya; Akuntansi dan Pengendalian. , Alih Bahasa Tim Salemba Empat. Jakarta : Salemba Empat jakarta.

Harsojuwono, B., A. (2008). Pentingnya Penerapan Commodity System Assessment Method (CSAM) Pada Penanganan dan Distribusi Produk Hortikultura. Orasi IImiah Guru Besar. UNUD, Badung.

Hartwich, F.T.J., Engler, A., González, C., Ghezan, G., Jorge, M.P., Vázquez, A.,, Silva, J.A., Espinoza, J.J., \& María, V. G. (2007). Building Public-Private Partnerships for Agricultural Innovation. Food Security in Practice technical guide series. Washington, D.C.: International Food Policy Research Institute. doi: 10.2499/9780896297715fsp4 
Kaplinsky, R. (2000), "Spreading the gains from globalisation: What can be learned fromvalue chain analysis?", Journal of Development Studies, Vol. 37, No.2., pp 117-146.

Kementerian PPN/Bappenas. (2014). Kajian Strategi Pengelolaan Perikanan Berkelanjutan. www. bappenas.go.id.

La Gra, J. (2016). Commodity Systems Assessment Methodology for Value Chain Problem and Project Identification : A first step in food loss reduction. San Jose, C.R.: IICA. 246 p.

Lindert, P. H. \& Ch. P. Kindleberger. (1993). Ekonomi Internasional. Alih Bahasa Burhanuddin Abdullah. Edisi kedelapan. Jakarta.: Erlangga.

Otto, B. (2008). Meninggalkan Ketergantungan pada Komoditas: Menggeser Kekuasaan ke Bawah Dalam Rantai Nilai Fokus pada produk unggulan dan layanan paket lengkap dapat membantu Indonesia mempertahankan nilai dalam rantai nilai. competitiveness at the FRONTIER tema Rantai Nilai, Juli 2008. Retrieved from https://pdf. usaid.gov/pdf_docs/Pnads405.pdf.

PNPM Mandiri Pengolahan Hasil Perikanan Kemeterian Kelautan dan Perikanan (2014). Minapolitan Budi daya Kab. Kepulauan Morotai. Jakarta: Direktorat Kawasan Budi daya - DJPB.

Ponnusamy, K. (2013). Impact of public private partnership in agriculture: A review. Indian Journal of Agricultural Sciences 83 (8). Retrived from http://epubs.icar.org.in/ejournal/index.php/ IJAgS/ article/ view/ 31981

Porter, M.E. (1985). Competitive Advantage - Creating a Sustaining Superior Performance. New York: The Free Press.

Susanto, A.N. \& M.A. Sirappa. (2007). Karakteristik dan ketersediaan data sumber daya lahan pulau-pulau kecil untuk perencanaan pembangunan pertanian. Jurnal Penelitian dan Pengembangan Pertanian 26(2): 41-53.

Tarunamulia., Hasnawi., Taukhid, I., \& Kamariah. (2020). Environmental characteristics and development prospective of sea cage aquaculture in Morotai Island Regency. IOP Conference Series: Earth and Environmental Science. doi: 10.1088/1755$1315 / 564 / 1 / 012024$

Taufik M. (2012). Strategi pengembangan agribisnis sayuran di Sulawesi Selatan. Jurnal Penelitian dan Pengembangan Pertanian 31(2): 43-50. 